\title{
Social Media and Political Participation: Are Facebook, Twitter and YouTube Democratizing Our Political Systems?
}

\author{
Robin Effing ${ }^{1}$, Jos van Hillegersberg ${ }^{1}$, and Theo Huibers ${ }^{2}$ \\ ${ }^{1}$ Department of Information Systems \& Change Management, \\ University of Twente, School of Management and Governance, \\ P.O. Box 217, 7500 AE, Enschede, The Netherlands \\ ${ }^{2}$ Human Media Interaction, University of Twente, Enschede, The Netherlands \\ \{r.effing, j.vanhillegersberg, t.w.c.huibers\} @utwente.nl
}

\begin{abstract}
This paper presents the results of a literature review in regard to Social Media and participation. Besides that, to understand the meaning and impact of Social Media on elections, we show field results from the 2010 and 2011 elections in the Netherlands. There are several challenges when it comes to engaging people in party politics. The current findings in literature show us that previous efforts to shape public participation with prior Internet tools did not meet expectations. With Social Media this could change, because participation seems to be the key concept that explains the difference between 'old' web and 'new' Social Media. In the Netherlands, Social Media did not significantly influence voting behaviour during the local elections (2010/2011). But, during the national elections (2010), politicians with higher Social Media engagement got relatively more votes within most political parties. In conclusion, we propose a future research agenda to study how political parties could benefit from Social Media to reinvent and improve the way they work with their members and volunteers.
\end{abstract}

Keywords: Social Media, Internet, Participation, Politics, Elections.

\section{Introduction}

Recent years have seen a decline in non-profit community participation such as political party membership. Also, there are several challenges when it comes to engaging people in party politics [1,2]. Contrary to popular expectations, the rise of the Internet did not result in increased levels of public participation $[3,4]$. On top of that, many political parties are afraid to lose control over their message when they delegate power and authority to the public $[3,5]$.

At the same time, Internet use by citizens is becoming more social and participatory. Today, social websites such as Facebook, Twitter, LinkedIn, MySpace, Wikipedia, Flickr and YouTube are the number one activity on the web. As of April 2011, Facebook has approximately 600 million registered users and according to market researcher ComScore [7], people are spending more time on Facebook than on 
Google. The use of mobile Internet gave an additional boost to the use of Social Media. Organizations such as political parties are trying to keep up with this changing environment. Most of them are struggling to implement Social Media to their benefit. It seems that political parties are just riding the wave of Social Media without any strategy. Organizations tend to underestimate the implementation of Social Media because they do not understand them.

The opposite was true in the case of Obama's election campaign; it was, for a large part, systematically based on Social Media [6,10,11,12,13,14,53]. Next to his own website, Obama used fifteen Social Media sites to run his campaign. He understood the power of complementing offline work with an online campaign. He systematically linked the online community to offline activities such as fundraising [15]. Obama's use of Social Media was an important aspect of his overall campaign strategy. Another positive case was the campaign of Ségolène Royal during the French elections in 2007. She managed to connect with a massive online crowd [5]. Due to her online campaign, party membership increased from 120,000 to 200,000 members [16]. $90 \%$ of increase had not been a member of a political party before. With examples of mass mobilizations such as civilian protests in Iran and other Middle-Eastern countries, it is safe to argue that Social Media are changing the game of politics.

While Social Media have the potential to dramatically change the relationships of individuals to society [17], we have to discover what Social Media mean and how to implement them for maximum benefits. There is no clear definition of Social Media, as we will indicate in a next section. Political parties often have traditional community structures. Organizations with such structures can probably benefit from Social Media since they depend on active member participation. Hence, we decided to perform a systematic literature review.

This paper aims to show the results of a literature review in regard to Social Media and participation. As one of the results of the literature review, we will further define Social Media and participation. We will also introduce some field results and a research agenda.

\section{Literature Review}

A systematic literature review was conducted to deliver a broad overview of disciplines, authors and journals related to Social Media and participation. We used the electronic scientific databases ISI Web of Science, Picarta, Scopus, EBSCO INSPEC and EBSCO Business Source Elite. Various keywords were used to search those databases. The first keyword is "Social Media". The second keyword is "participation". We also used the following related terms for the concept of Social Media: "Social Internet", "Social Web", "Social Network Site(s)", "User Generated Content", "Web 2.0" and "Crowdsourcing". During the research, one search query was added because many retrieved articles included the keyword: "e-participation". Related terms of participation such as "engagement", "involvement" and "commitment" did not deliver additional results, and were left out. The next step was selecting relevant papers from the search results by analysing abstracts from retrieved records. We used a-priori selection criteria; for example, articles about user participation in system design were excluded. 
Some research disciplines were more frequently selected than others. Especially, social sciences are ahead of Social Media research. Table one shows the articles by topic.

Table 1. Articles by topic

\begin{tabular}{lll}
\hline Topic category & Number of articles & Percentage of total \\
\hline $\begin{array}{l}\text { Citizen participation } \\
\text { Use and social }\end{array}$ & 40 & $35 \%$ \\
behaviour & 23 & $20 \%$ \\
$\begin{array}{l}\text { Online community } \\
\text { design }\end{array}$ & 14 & $12 \%$ \\
$\begin{array}{l}\text { Politics and } \\
\text { democracy }\end{array}$ & 13 & $12 \%$ \\
Other & 23 & $20 \%$ \\
\hline
\end{tabular}

Some areas of interest are more frequently studied than others. Most of the publications relate to the topic of citizen participation, especially in local government. Several studies were carried out on local electronic participation [18,19]. Only 12 percent of all articles are about politics and democracy.

Based on the analysis of the articles from a political and public participation perspective, the following insights emerge.

Previous efforts to shape public participation with Internet tools did not meet expectations. There has been very little success with prior Social Media tools such as online discussion forums, chat and online surveys [20,21,22].

Many authors $[23, \ldots, 34]$ address the issue of defining and measuring e-participation. From the literature selection, no less than 13 different participation ladders are available and no consensus exists about them [26,32,35]. In general, the participation ladders define a certain degree of user participation, from informing to empowerment. Because of the inconsistent ways of defining and measuring participation in the literature, it is difficult to measure and compare e-participation. In the next section, we use the frequently cited participation ladder from Macintosh [26,30,31]. In our opinion, Macintosh's model is most suitable for describing Social Media participation levels.

With the changing Internet environment, there are opportunities to involve and empower citizens in campaigns and work of representatives and government. This so called Crowdsourcing, is a major challenge, which needs a different perspective on citizens. It is necessary to change the perspective from content consumers to content producers (prosumers) [36,37,38,39]. In most cases, this change is difficult. It requires additional trust in the community. And, it turns out that only a minor group of users is responsible for almost all the contributions. So called super contributors [39]. Hence, this may result in creating a new political 'web' elite instead of an equal representation of citizens.

Another relevant topic, indicated in literature, is the concept of digital divide. Online political participation is not equally represented. Certain people are more interested. According to various authors $[5,40,41,42]$, the political active on the web are welleducated males with relatively high income and even relatively high age. But, the younger they are, the more they post and participate [36]. In many cases the politically interested people online, are the same as the politically interested people offline. 
Secondly, next to political and citizen participation, studies are available related to societal use and social behaviour. In the latter, for instance, findings support the idea that the use of Social Media increases social capital $[43,44,45,46,47,48]$ that is related to political participation [53].

As the participation research field is much broader than citizen participation, more research should be carried out in regard to political parties, their members and elections. With the insights of the literature review, we are able to define Social Media and participation.

\section{Social Media and Participation Defined}

One of the first definitions of Social Media, published in scientific literature, comes from Kaplan and Haenlein [49]: "Social Media is a group of Internet-based applications that build on the ideological and technological foundations of Web 2.0, and that allow the creation and exchange of User Generated Content." This definition makes clear that Social Media is not a completely new generation of Internet tools. Social Media rely heavily on the concept of Web 2.0. "Web 2.0 is a term that was first used in 2004 to describe a new way in which software developers and end-users started to utilize the World Wide Web; that is, as a platform whereby content and applications are no longer created and published by individuals, but instead are continuously modified by all users in a participatory and collaborative fashion" [49].

Hence, it can be argued that the term Social Media is mainly a new label for existing technology. Tim Berners-Lee, the founder of the World Wide Web, already expected this social use of the Internet from the start: "The Web is more a social creation than a technical one. It was designed for a social effect to help people work together" [50]. Kaplan and Haenlein emphasize, in their definition, that users can participate more actively in processes of organizations by using web technology.

Participation seems to be the key concept that explains the difference between 'old' web and 'new' Social Media, although basic tools for interaction such as chat and forum were available in the early days of the World Wide Web. The problem with the definition of Kaplan and Haenlein is that they do not include the power of underlying social networks with personal profiles, as pointed out by Boyd and Ellison [51]. The media hype around the term Web 2.0 is decreasing. The trend is downhill. Today, people are talking about Social Media. The Google trend comparison in figure one illustrates this.

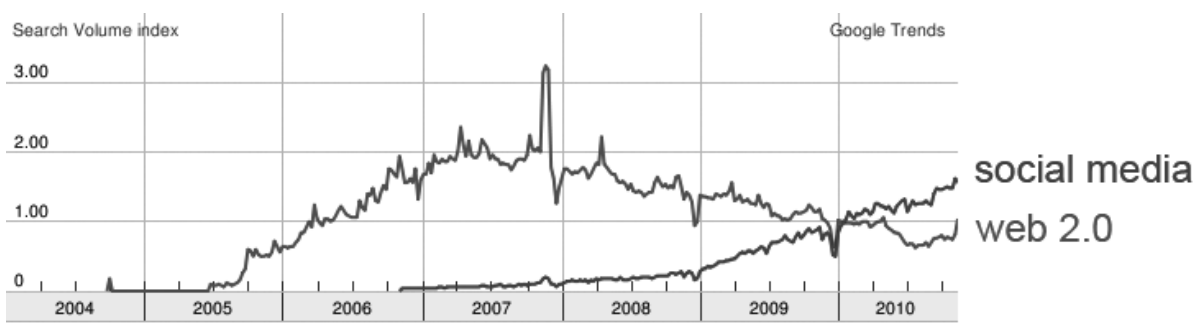

Fig. 1. Google trends: "Web 2.0" against "Social Media" 
A key factor of Web 2.0 and Social Media is participation. Therefore, let us define participation more precisely. Grönlund [26] defines participation as "the specific activity of doing things together". Xie, Bo and Jaeger define political participation as "behaviours aimed at shaping governmental policy, either by influencing the selection of government personnel or by affecting their choices".

Macintosh [26,30,31] created a participation ladder with three stages of online participation, which is useful for explaining the Social Media phenomenon. First, there is eEnabling. This is mainly about giving access and information to members, citizens or users. The second stage is e-Engaging. During this stage, people can interact with the organization and start a dialogue. People are being consulted for certain projects, decisions or activities for instance with forums and polls. The third stage is e-Empowering. This stage is about working together with users, members or citizens. Empowering them with responsibilities, tasks and options to collaborate with the organization.

Take the Lego Factory website for example: Lego fans can design, share and order their own virtually designed products. Or, Obama's followers making and sharing their own Obama related campaign video clips on YouTube [15].

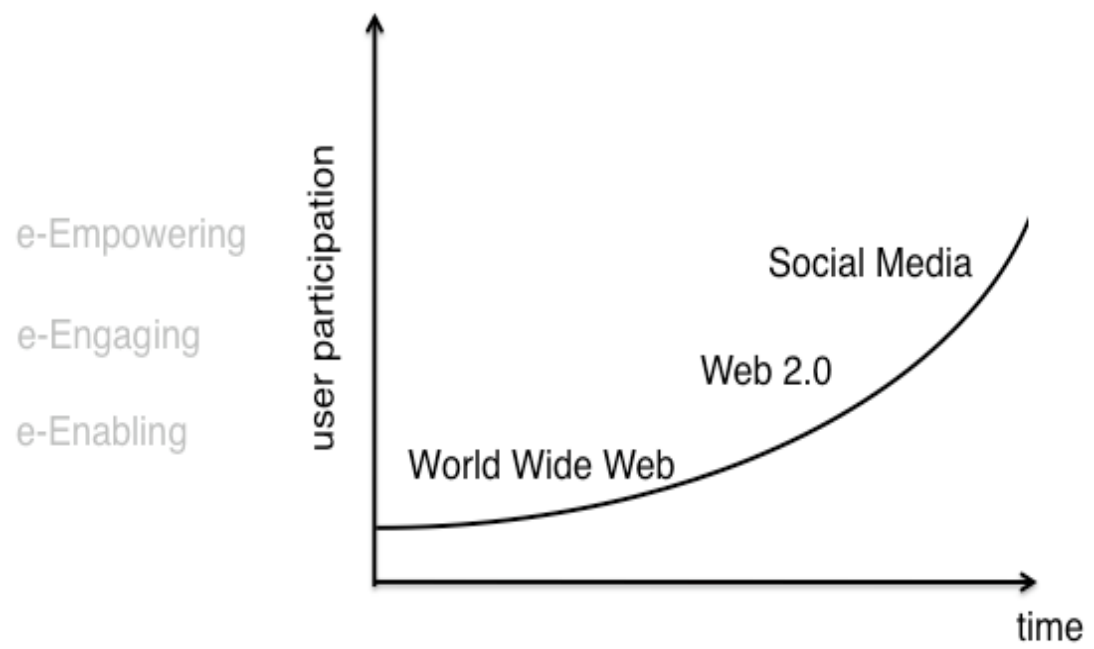

Fig. 2. Social Media evolution model

Figure two presents the model for understanding Social Media as an evolution out of previous web constructs. The vertical axis represents the level of user participation by indicating the typical degree of participation from e-Enabling, e-Engaging to eEmpowering. The horizontal axis is time. When time passes, new labels and definitions are created to understand how the Internet develops. Boundaries in this model are not precisely defined, but gradual. It shows the evolution from World Wide Web, to Web 2.0, to Social Media. Web 2.0 is a new stage where the user participation increases. The emphasis is more on e-Engaging tools.

This model makes clear that Web 2.0 is not a completely new kind of the web, but a new stage reached with higher user participation. With the current increasing use of Social Media, the user participation level can increase dramatically. This does not mean that e-Empowering was not possible during the beginning of the World Wide 
Web. Social Media is a new stage of development where users are more actively participating than ever.

With the rise of Social Media, politicians and government could create opportunities for political participation: enabling, engaging and empowering followers for various benefits.

\section{Field Study Dutch Elections}

To understand the meaning and impact of Social Media on political elections, we conducted a series of empirical research projects during the 2010 and 2011 elections in the Netherlands. Firstly, we were interested if there were empirical signs that Social Media usage by politicians has an effect on voting behaviour. By comparing Social Media engagement of political candidates on the one hand and the individual votes on the other hand we are able to calculate if there is a relationship between them.

As an accepted framework for measuring Social Media engagement is lacking and the participation ladder from Macintosh is too abstract for measuring, we decided to develop our own evaluation framework for Dutch elections, the: "Social Media Indicator" (SMI). This framework consists of a standardized way of measuring the Social Media participation of politicians and their interactivity with the public.

This Social Media Indicator is a helpful tool in indicating the level of engagement of politicians in social media and the degree in which they interact with their followers on these media. The indicating questions from the Social Media Indicator are presented in table 2 .

Table 2. Social Media Indicator

Social Media Indicator (SMI)

Does the politician maintain a personal Blog?

In case of a Blog, how many replies?

In case of a Blog, how many Blog Posts?

Does the politician have a profile at Hyves?

In case of personal Hyves, what is the total number of scraps?

In case of personal Hyves, what is the view count?

In case of personal Hyves, how many friends?

Does the politician have a profile at Twitter?

Based on latest 200 tweets, how many retweets?

In case of personal Twitter account, how many tweets?

Based on latest 200 tweets, how many replies?

In case of personal Twitter account, how many following?

In case of personal Twitter account, how many followers?

Does the politician have a profile at Facebook?

In case of personal Facebook account, how many friends?

In case of personal Facebook account, how many likes?

Does the politician have a YouTube channel?

How many videos are posted on this personal channel?

Based on all videos, how many times are they watched?

Based on all videos, how many comments?

Based on this channel, how many subscribers? 
Because of the large number of different Social Media, we did not try to cover all social media in our analysis. We thought it was more important to include the social media with the highest reach in the Netherlands. Hence, we included Hyves, Twitter, Facebook and YouTube. Hyves is still the largest social network site in the Netherlands. On top of that, we added personal blogs to the Social Media Indicator. Personal blogs from politicians are often used to connect to citizens and have a large reach.

By focusing on the measurement of contribution levels of the politician and counting interaction with others, we include all levels of participation (e-enabling, e-engaging and e-empowerment). This current measurement system does not differentiate between these different levels of participation yet.

By observing the set of predefined standardized indicators, we can calculate a total SMI score for each politician in the Netherlands. This score is compared to the personal votes this politician got during elections. With this comparison, we are able to see if Social Media usage makes a difference within the party. Do party candidates engaged in Social Media get more votes than colleagues who do not? Statistically, we compare two variables, on the one hand the SMI score of a candidate, on the other hand the votes this particular candidate received. We use scatterplot diagrams and Spearman's rank correlation coefficient to find dependencies.

After applying the above method to three different elections in the Netherlands, the results are as follows. Social Media does not play a big role yet in the local state (2011) and municipality (council) elections (2010) in the Netherlands. The engagement levels of politicians were very low. Because of this low participation, it was very difficult to calculate correlations. When only two or three people of a party engage actively in social media, it does not make sense to compare them to a much larger group of inactive users.

During the national elections of the House of Representatives (Tweede Kamer der Staten-Generaal) of June 9, 2010 we got clear results because participation levels in Social Media were much higher. We calculated the SMI for all candidates $(n=676)$ and compared it to the votes. We excluded the first five candidates from every candidate list, because we assumed that politicians with high list positions have easy access to mass media such as television, radio and print media. In those cases, it is very difficult to isolate the effect of Social Media from other, more traditional media.

Within nine parties, out of sixteen, we found a positive significant correlation. Politicians with higher Social Media engagement got relatively more votes within most parties, as illustrated in table 3 .

Table 3. SMI correlation with votes at Dutch national political parties

\begin{tabular}{lll}
\hline Positive correlation & Positive correlation & No correlation \\
$>0.5$ & $>0.3$ & $<0.3$ \\
\hline Partij van de Dieren & CDA & PVV \\
Piratenpartij & PVDA & SGP \\
& Christenunie & TON \\
& SP & Nieuw NL \\
& TON & MenS \\
& Lijst17 & Partij één \\
& D66 & \\
\hline
\end{tabular}


The differences between parties could be a result of differences in target audience, content strategy and other factors, but these factors are not yet thoroughly explored.

Additionally, the higher scores for certain candidates could reflect that a party candidate has an already large social network in the real world. Nevertheless, there seems to be a powerful influence from Social Media on reaching and influencing voters.

To increase the value of our findings, we conducted a few qualitative, open faceto-face interviews with party members and board members of political parties. Interviews held with the parties PvdD and CDA helped us to improve our understanding of the relationship between social media participation and votes. Measuring points that were exceptions could be explained by other influence factors. And, it seems that it makes a difference if politicians use Social Media with or without strategy.

Use of Social Media does not always result in a more effective political campaign. It heavily depends on how its use is designed, which emphasizes the need for further research.

\section{Future Research Agenda}

Political parties and similar non-profit organizations could benefit from Social Media to improve the way they work with their members and volunteers. However, the various ways to use Social Media and their effects on member participation are not well understood. Therefore, two research questions for further research are articulated.

RQ1: How can non-profit organizations - with community structures - such as political parties increase member participation by implementing Social Media?

RQ2: What are the design principles for optimal implementation of Social Media, as a participation instrument, at non-profit organizations with traditional communities?

To answer these questions, we plan to conduct multiple longitudinal case studies. According to Waters et al [8], "longitudinal studies could offer insights into how organizations change their social networking strategies over time, and case studies should be conducted to help offer insights for other organizations based on efforts that have both succeeded and failed". In the near future, we will study the changing dynamics of the city council of a large Dutch municipality influenced by the participatory use of Social Media.

We will do a longitudinal study, comparing two variables: Social Media Participation (SMCP), and Offline Community Participation (OCP). The evaluation of both offline and online participation is a new and emerging area, which needs further research [52].

Our next goal is to design an evaluation framework for Social Media and community participation. Besides measuring of actual participation, it is important to look at social aspects of community participation as well, such as beliefs, attitudes and sense of community.

Our broader goal is to make clear to which extent Social Media can be used as a community-strengthening tool in non-profit organizations with community structures such as church, trade-unions and political parties. Therefore, in June 2011, we started a longitudinal case study at the Dutch parish H. Plechelmus from the Roman Catholic Church. 


\section{References}

1. Edelmann, N., Hoechtl, J., Parycek, P.: eParticipation for Adolescent Citizens (in Austria). In: Macintosh, A., Tambouris, E. (eds.) ePart 2009. LNCS, vol. 5694, pp. 163-174. Springer, Heidelberg (2009)

2. Livingstone, S., Bober, M., Helsper, E.: Active participation or just more information? Information, Communication \& Society 8, 287-314 (2005)

3. Davis, A.: New media and fat democracy: the paradox of online participation. New Media \& Society 12, 745-761 (2009)

4. Van Dijk, J.A.G.M.: The network society: social aspects of new media. SAGE, Thousand Oaks (2006)

5. Lilleker, D.G., Pack, M., Jackson, N.: Political Parties and Web 2.0: The Liberal Democrat Perspective. Political Studies 30, 105-112 (2010)

6. Christakis, N.A., Fowler, J.H.: Connected: The Surprising Power of Our Social Networks and How They Shape Our Lives. Little, Brown and Company (2009)

7. Ray, A.: The Implications Of Consumers Spending More Time With Facebook Than Google, Forrester Blogs, http: //blogs.forrester.com/augie_ray/ (accessed November 26, 2010)

8. Waters, R.D., Burnett, E., Lamm, A., Lucas, J.: Engaging stakeholders through social networking: How nonprofit organizations are using Facebook. Public Relations Review 35, 102-106 (2009)

9. Faust, W., Householder, L.: Get Real and Prosper: Why Social Media Demands Authentic Brands. Design Management Review 20, 45-51 (2009)

10. Lutz, M.: The social pulpit. Barack Obama's Social Media toolkit. Edelman (2009)

11. Talbot, D.: How Obama Really Did It: The social-networking strategy that took an obscure senator to the doors of the White House. Technology Review, 9/10 (2008)

12. Citron, D.K.: Fulfilling Government 2.0's Promise with Robust Privacy Protections. Arguendo, The George Washington Law Review 78, 822-845 (2010)

13. Greengard, S.: The First Internet President. Communications of the ACM 52(2), 16-18 (2009)

14. Stirland, S.: Propelled by Internet, Barack ObamaWins Presidency, Wired Magazine (November 4), http://www.wired.com/threatlevel/2008/11/propelledby-in/

15. Ren, J., Meister, H.P.: Drawing Lessons from Obama for the European Context. The Internetional Journal of Public Participation 4, 12-30 (2010)

16. Montero, M.D.: Political e-mobilisation and participation in the election campaigns of Ségolène Royal (2007) and Barack Obama (2008). Quaderns Del Cac 33, 27-34 (2009)

17. Lewis, S., Pea, R., Rosen, J.: Beyond participation to co-creation of meaning: mobile social media in generative learning communities. Social Science Information 49, 351-369 (2010)

18. Borge, R., Colombo, C., Welp, Y.: Online and offline participation at the local level: A quantitative analysis of the Catalan Municipalities. Information, Communication \& Society 12, 899-928 (2009)

19. Mambrey, P.: From Participation to e-Participation: The German Case. In: ICEGOV 2008, pp. 355-360 (2008)

20. Phang, C.W., Kankanhalli, A.: A Framework of ICT Exploitation for E-Participation Initiatives. Communications of the ACM 51, 128-132 (2008) 
21. Roeder, S., et al.: Public Budget Dialogue: An Innovative Approach to E-Participation. In: Böhlen, M.H., Gamper, J., Polasek, W., Wimmer, M.A. (eds.) TCGOV 2005. LNCS (LNAI), vol. 3416, pp. 48-56. Springer, Heidelberg (2005)

22. Stern, E., Gudes, O., Svoray, T.: Web-based and traditional public participation in comprehensive planning: a comparative study. Environment And Planning 36, 1067-1085 (2009)

23. Anadiotis, G., et al.: Facilitating Dialogue - Using Semantic Web Technology for eParticipation. In: Aroyo, L., Antoniou, G., Hyvönen, E., ten Teije, A., Stuckenschmidt, H., Cabral, L., Tudorache, T. (eds.) ESWC 2010. LNCS, vol. 6088, pp. 258-272. Springer, Heidelberg (2010)

24. Conroy, M.M., Evans-Cowley, J.: E-participation in planning: an analysis of cities adopting on-line citizen participation tools. Environment and Planning 24, 371-384 (2006)

25. French, S., Insua, D.R., Ruggeri, F.: e-Participation and Decision Analysis. Decision Analysis 4, 211-226 (2007)

26. Grönlund, Å.: ICT Is Not Participation Is Not Democracy: eParticipation Development Models Revisited. In: Macintosh, A., Tambouris, E. (eds.) ePart 2009. LNCS, vol. 5694, pp. 12-23. Springer, Heidelberg (2009)

27. Hansen, H.S., Reinau, K.H.: The Citizens in E-Participation. In: Wimmer, M.A., Scholl, H.J., Grönlund, Å., Andersen, K.V. (eds.) EGOV 2006. LNCS, vol. 4084, pp. 70-82. Springer, Heidelberg (2006)

28. Rose, J., Sæbø, Ø.: Designing Deliberation Systems. The Information Society 26 (2010)

29. Sæb $\varnothing, \varnothing .$, Rose, J., Molka-danielsen, J.: eParticipation: Designing and Managing Political Discussion Forums. Social Science Computer Review (2010)

30. Medaglia, R.: Measuring the diffusion of eParticipation: A survey on Italian local government. Information Polity 12, 265-280 (2007)

31. Sommer, L., Cullen, R.: Participation 2.0: a Case Study of e-Participation within the New Zealand Government New Zealand New Zealand Abstract. In: 42nd Hawaii International Conference on System Sciences 2008 (2009)

32. Loukis, E., Xenakis, A.: Evaluating Parliamentary e-Participation. In: ICDIM 2008, pp. 806-812 (2008)

33. Lourenço, R.P., Costa, J.P.: Incorporating citizens' views in local policy decision making processes. Decision Support Systems 43, 1499-1511 (2007)

34. Koh, J., Kim, Y.-g., Butler, B., Bock, G.-w.: Encouraging Participation. Communications of the ACM 50, 69-74 (2007)

35. Peristeras, V., Mentzas, G., Tarabanis, K.A., Abecker, A.: Transforming E-government and E-participation. IEEE Intelligent Systems, 14-19 (September 2009)

36. Wei, L., Yan, Y.: Knowledge Production and Political Participation: Reconsidering the Knowledge Gap Theory in the Web 2.0 Environment. In: ICIME 2010 (2010)

37. Rebillard, F., Touboul, A.: Promises unfulfilled? Journalism 2.0, user participation and editorial policy on newspaper websites. Media, Culture \& Society 32, 323-334 (2010)

38. Brabham, D.C.: Crowdsourcing the Public Participation Process for Planning Projects. Planning Theory 8, 242-262 (2009)

39. Flew, T., Wilson, J.: Journalism as social networking: The Australian youdecide project and the 2007 federal election. Journalism 11, 131-147 (2010)

40. Hibberd, M.: E-Participation, Broadcasting and Democracy in the UK. Convergence: The International Journal of Research into New Media Technologies 9, 47-65 (2003)

41. Moreira, A.M., Möoller, M., Gerhardt, G., Ladner, A.: E-Society and E-Democracy. In: eGovernment on Symposium 2009 (2009) 
42. Saglie, J., Vabo, S.I.: Size and e-Democracy: Online Participation in Norwegian Local Politics What Promotes or Inhibits Local Participation on. Scandinavian Political Studies 32, 382-401 (2009)

43. Brandtzæg, P.B., Heim, J.: Why People Use Social Networking Sites. In: Ozok, A.A., Zaphiris, P. (eds.) OCSC 2009. LNCS, vol. 5621, pp. 143-152. Springer, Heidelberg (2009)

44. Ellison, N.B.: The Benefits of Facebook Friends: Social Capital and College Students' Use of Online Social Network Sites. Journal of Computer-Mediated Communication 12, pp. 1143-1168 (2007)

45. Karahasanović, A., et al.: Co-creation and user-generated content-elderly people's user requirements. Computers in Human Behavior 25(3), 655-678 (2009)

46. Tomai, M., et al.: Computers \& Education Virtual communities in schools as tools to promote social capital with high schools students. Computers \& Education 54, 265-274 (2010)

47. Valenzuela, S., Park, N., Kee, K.F.: Is There Social Capital in a Social Network Site?: Facebook Use and College Students. Journal of Computer-Mediated Communication 14, 875-901 (2009)

48. Vergeer, M.: Consequences of media and Internet use for offline and online network capital and well-being: A causal model approach. Journal of Computer-Mediated Communication 15, 189-210 (2009)

49. Kaplan, A.M., Haenlein, M.: Users of the world, unite! The challenges and opportunities of Social Media. Business Horizons, 59-68 (2010)

50. Berners-Lee, T., Fischetti, M.: Weaving the Web: The Original Design and Ultimate Destiny of the World Wide Web by Its Inventor, Paw Prints (2008)

51. Boyd, D.M., Ellison, N.B.: Social Network Sites: Definition, History, and Scholarship. Journal of Computer-Mediated Communication 13, 210-230 (2008)

52. Macintosh, A., Whyte, A.: Evaluating how e-participation changes local participation. In: eGovernment Workshop 2006 (eGOV 2006) (September 11, 2006)

53. Zhang, W., Johnson, T.J., Seltzer, T., Bichard, S.L.: The Revolution Will be Networked. Social Science Computer Review 28, 75-92 (2010)

54. Xie, B., Jaeger, P.T.: Older Adults and Political Participation on the Internet: A Crosscultural Comparison of the USA and China. Journal of Cross Cultural Gerontologyurnal of Cross Cultural Gerontology, 1-15 (2008) 